\title{
Calvin on Human Reason
}

\begin{abstract}
Author:
Nicolaas Vorster ${ }^{1}$

Affiliation:

${ }^{1}$ Faculty of Theology,

Northwest-University,

Potchefstroom Campus,

South Africa.

Correspondence to:

Nicolaas Vorster

Email:

nico.vorster@nwu.ac.za

Postal address:

18 Stormstreet,

Potchefstroom 2531, South

Africa

Dates:

Received: 17 Feb. 2014

Accepted: 06 June 2014

Published: 02 Oct. 2014

How to cite this article:

Vorster, N., 2014, 'Calvin on

Human Reason', In die Skriflig

48(1), Art. \#1811, 9 pages.

http://dx.doi.org/10.4102/

ids.v48i1.1811
\end{abstract}

\section{Copyright:}

(C) 2014. The Authors.

Licensee: AOSIS

OpenJournals. This work

is licensed under the

Creative Commons

Attribution License.

Read online:
In his recent book The Unintended Reformation, Brad Gregory makes the statement that the Reformation replaced the teleological social ethics of Roman Catholicism based on virtue with formal social ethics based on rules and enforced by magistrates, because they regarded human reason as too depraved to acquire virtue. The result, according to Gregory, is that the relation between internalised values and rules were undermined. This article asks whether this accusation is true with regard to Calvin. The first section discusses the intellectual environment of Calvin's day - something that inevitably influenced his theory on reason, whilst the second part analyses Calvin's view on the created nature of reason. The third section investigates Calvin's view on the effects of sin on reason; and the fourth section discusses Calvin's perspective on the relation between grace and reason. The article concludes that Gregory's accusation against the Reformation is not applicable to Calvin. Gregory fails to take into account Calvin's modified position that the imago Dei was not totally destroyed by sin as well as his teaching on common grace that maintains that even non-believers are able to acquire virtue through the common grace of God.

Calvyn oor Menslike Rede. In sy onlangse boek, The Unintended Reformation, maak Brad Gregory die stelling dat die Reformasie die substantiewe teleologiese deugde-etiek van die Rooms-Katolisisme vervang het met ' $n$ formele etiek gebaseer op reëls wat deur magistrate afgedwing moet word. Die Reformasie was, volgens Gregory, van mening dat die menslike rede sodanig deur sonde geskend is dat die mens nie langer deugde kan beoefen nie. Dit het tot ' $n$ skadelike skeiding tussen waardes en reëls gelei. Hierdie artikel ondersoek die vraag of Gregory se stelling op Calvyn van toepassing is. Die eerste afdeling bespreek die intellektuele omgewing waarin Calvyn gewerk het. Tweedens word Gregory se siening van die geskape struktuur van die rede bespreek. Die derde afdeling ondersoek Calvyn se siening oor die effek van sonde op die menslike rede; en in die vierde afdeling word daar gekyk na Calvyn se perspektief op die verhouding tussen genade en rede. Die artikel kom tot die slotsom dat Gregory se bewering nie op Calvyn van toepassing gemaak kan word nie. Gregory neem verkeerdelik aan dat Calvyn die siening handhaaf dat die mens se beeldskap heeltemal deur die sonde vernietig is. Hy verreken geensins Calvyn se doktrine oor God se algemene genade nie. Hierdie doktrine stel onder meer dat God se algemene genade dit vir alle mense moontlik maak om deugde te beoefen.

\section{Introduction}

Calvin is often accused of emphasising the perverted nature of human reason to such a degree that he risks obliterating the human side of the divine-human relationship. The argument is that Calvin's setting of a totally depraved humanity against an all-powerful Divine, undermines the moral agency of the human being (cf. Billings 2005:317).

In his recent book, The Unintended Reformation, Brad Gregory argues that the Reformation's radical position on human sinfulness and its rejection of a teleological ethics makes a cohesive and sustainable social ethics basically impossible. He argues that the Reformers did not allow for a virtue ethics because 'salvation had nothing to do with human freedom or the human will' (Gregory 2012:206). Whereas Scholasticism held that all humans possess the inherent rational capacity to comprehend the human telos through 'a gradual process of habituation and a rational disciplining of the passions', the Reformers maintained that the human cannot attain its telos by acquiring virtues through rational means (Gregory 2012:207). Gregory (2012) states it thus:

Twisted human wills retained no orientation toward the good, so there was nothing to tutor - no voluntas only noluntas. (p. 208)

The result was that the Reformation had to revert to a formal ethics of rules and rights to make a social ethics possible. Instead of a habituation in Christian virtues, ethical regimes had to be constructed 
by establishing moral rules based on Scripture, and these had to be enforced by magistrates and pastors. Whilst Christians were freed and sanctified by God in order to do good works, the reprobate had to be forced to conform to laws consistent with the Gospel, and magistrates were obliged to 'punish their transgressions' (Gregory 2012:208). Gregory argues that the 'legalistic' formal ethics of the Reformation, together with other social developments, contributed to the demise of a substantive ethics that integrates politics and morality. The end result was a morality based on the 'following of rules' and not the 'imitation of Christ' (Gregory 2012:210, 212). According to Gregory this dissolution of the relation between value and rule would eventually contribute to the 'subjectivication of Western morality' (cf. Gregory 2012:212).

The question this article will probe, is the following: Does Calvin's view of the perversion of human reason allows space for a substantive social ethics that integrates value and rule, or is Gregory's claim that the Reformers had to revert to a formal kind of ethics because of their rejection of a teleological ethics, applicable to Calvin? The article will reflect on this by firstly analysing the intellectual environment within which Calvin formulated his view on reason. The second section will discuss his understanding of reason as endowment, whilst the third section will study his stance on the effects of sin on reason. The fourth section will probe his view on the relation between grace and reason; where after an answer to the question posed, will be formulated.

\section{The intellectual environment of the 16th century}

Calvin framed his theology against the background of 16th century Scholasticism that exhibited optimism in the human's ability to know things as they really are. Roman Catholic theology subscribed to the Aristotelian or Scholastic notion that the order of things are intelligible, because meaning is embedded in the structure of things through the existence of ideal patterns or forms that serve as archetypes for individual phenomena. Thomas Aquinas's teleological ethics, in particular, dominated Catholic thinking in the Late Medieval Ages. He utilised Aristotle's notion of potency and act to argue that all human beings possess an innate capacity to understand their telos. Central to Aquinas's thought was the idea that human beings are moved by habits that are, in essence, dispositions towards good and evil (Aquinas 1989:225, ST 1a2ae.49.4). Bad habits lead humans astray from God, whereas good habits perfect human actions by directing human passions within a specific context towards a good end (Aquinas 2005:14). By nurturing good habits and disciplining passions, humans can be assisted in comprehending their telos. However, the various habits need to be informed by the supernatural value of caritas that gives all 'virtuous behaviour its life and existence' by directing human beings towards a love for God and each other (Aquinas 2005:249; 1989:351, ST IIaIIae.23.8).

According to Aquinas, natural habits infused by caritas make a social ethics possible, because caritas integrates all the various habits and directs them towards the ultimate goal of serving God and our fellow human beings (Aquinas 1989:351, ST II-II.23.7). When our natural habits are utilised to acquire virtue and the goals of society are made compatible with the ultimate goal of caritas, true tranquillity and peace becomes possible (cf. Aquinas 2005:266; 1989:351, ST IIaIIae.23.8). Though Aquinas did not deny the importance of grace for attaining true knowledge, he regarded reality as fundamentally intelligible and accessible to human reason. His premise was that sin affects the human's desires, but does not have a decisive influence on reason. This limited approach to sin allowed him to construct a teleological ethics that is informed by a positive affirmation of reason. Aquinas's rationalism found an extreme expression in the 16th century in the Sorbonne, which held that sin did not affect the mind, only the lower faculties that are related to human desires (cf. Calvin 1859:454, CO 49:235). ${ }^{1}$

Various developments in the 16th century would, however, inaugurated an intellectual revolution that threatened the stable worldview of Scholasticism. The natural scientific discoveries of Galileo, Copernicus and Kepler challenged Aristotelian physics profoundly and caused the downfall of the Ptolemaic worldview. The fear of disturbing the universal patterns inherent in 'being' resided, whilst the scope of natural philosophy was no longer restricted to the discovery of the patterns and forms underlying the essence of things. Instead, instrumental forms of rationality that left thinkers prepared to experiment with and reconstruct reality, replaced Scholasticism's contemplative kind of natural philosophy. The Renaissance humanists attempted to reconstruct society by cultivating a sense of virtuosity, self-control and sound etiquette in society. The realist worldview of Scholasticism was seen as too sterile for such a reconstruction of society. They rejected Scholasticism's dependence on logic and the organisation of truths in rationally intelligible systems, instead of turning to rhetoric and practical knowledge (Bouwsma 1988:114). The Renaissance humanists preferred 'persuasion over rational conviction' and held a view of the human being as 'social rather than intellectual' (Bouwsma 1988:114). In their endeavour to reconstruct society, the Renaissance movement rediscovered classical sources that inspired them to engage in philological studies of the classical languages. The Scholastic attempt to preserve the ideal of an intelligible static order was eroding and was in danger of being replaced by the ideal of a dynamic order that can be reconstructed through instrumental rationality (Vorster 2013:35).

Calvin's epistemological reflections were inextricably linked to these developments. He took note of developments within the natural sciences ${ }^{2}$ and utilised the hermeneutical and philological methods of the Renaissance to understand Scripture. True to the scholarly tenets of Renaissance

1.The Calvin Opera volumes are sited as CO with an indication of the relevant volume and page, whilst the Supplementa Calviniana is sited as SC, also with an indication of page and volume. English quotations from John Calvin's 1559-Institutes are taken from Calvin 2008 .

2.See in this regard Calvin's Commentary on Genesis 1 (1847a:86, CO 23:45) where he explicitly refers to developments within astrology. 
humanism, Calvin rejected pure objectivism by relating knowledge to an understanding of the predicament of the self. He also abandoned the speculative and theoretical approach of Scholasticism in favour of an empirical approach that worked with the revealed Word and creation of God (cf. Edgar 2010:3). Perhaps the most pervasive humanist element in Calvin's thinking is the profound practical nature of his theology. The fundamental interest of his theology is not to contemplate God intellectually, but to understand the communion between God and human beings in Christ and the practical implications of this for all spheres of life.

\section{Human reason as endowment of God}

Calvin uses various terms when addressing the theme of faith and reason. The term he uses most frequently is sapientia [wisdom], but he also uses ratio [reason], cognitio [knowledge], fides [faith] and entendement [understanding] (cf. Engel 1988:73). Though he uses these terms mostly as synonyms, his frequent use of sapientia, most notably in the first sentence of his 1539 and 1559 Institutes, is noteworthy. Engel (1988:73) rightly states that Calvin uses sapientia as a 'comprehensive term for his religious epistemology'. Through sapientia he expresses his belief that faith and knowledge is inextricably linked to each other and that true knowledge is, first of all, practical and relational in nature.

Calvin's theory on knowledge starts with a surprising premise. In order to attain knowledge, the human being must be decentred from himself. True knowledge depends on knowledge of God and the human being him- or herself. The human being is not autonomous in nature and can therefore not attain true knowledge if he or she lives detached from God:

Our wisdom, insofar as it ought to be deemed true and solid wisdom, consists almost entirely of two parts: the knowledge of God and ourselves. But as these are connected together by many ties, it is not easy to determine which of the two precedes and gives birth to the other. For in the first place, no man can survey himself without forewith turning his thought towards the God in whom he lives and moves. (Calvin 2008, Inst. 1.1.1, CO 2:32)

For the human being to attain knowledge, he or she must contemplate 'the face of God' and thereafter descend to look into him- or herself (Calvin 2008, Inst. 1.1.2, CO 2:35). Only when we raise our thoughts to God and perceive his perfectness, we become displeased with ourselves (Calvin 2008, Inst. 1.1.2, CO 2:35). This 'ascend' to God is not a curious attempt to pry into God's essence, but it is a contemplation of God's works (Calvin 2008, Inst. 1.5.9, CO 2:47, 48). Here we see Calvin's empirical and practical approach towards knowledge at work. He relentlessly resists theoretical and philosophical speculation on God's divine nature. Instead we acquire knowledge by observing God's works that are revealed in creation and scripture.

Knowledge of God first of all shines forth in his fashioning of the universe. Calvin (cf. 2009:6, SC 11/1:15; 2008, Inst. 1.14.18,
CO 2:123) often depicts the created order as a theatre of God's glorious works. The created order reminds us that we are the 'workmanship' of God and that God is the 'origin and fountain of all goodness' (Calvin 2008, Inst. 1.2.2, CO 2:35). Calvin also uses the metaphor of creation as a 'mirror' in which we may behold God, who is otherwise invisible (Calvin 2008, Inst. 1.5.1, CO 2:41, 42). We cannot open our eyes without being compelled to behold God (Calvin 2008, Inst. 1.5.1, CO 2:41). The heavens and earth presents us with 'innumerable proofs' of God's majesty forcing itself even on the most illiterate (Calvin 2008, Inst. 1.5.2, CO 2:42). In the works of God the 'perfections of God are delineated as in a picture' and the whole of the human race is lured to attain knowledge of God (Calvin 2008, Inst. 1.5.10, CO 2:48).

Scripture provides an even more splendid revelation of God's works than the created universe, because it reveals God's redeeming action in Christ. We cannot know the 'mystery' of Christ or enter into a relationship with God without the knowledge the Gospel provides to us (Calvin 2008, Inst. 2.9.1, CO 2:310). The authority of Scripture rests upon God being it's Author and the Holy Spirit being the Guarantor of its truth (Calvin 2008, Inst. 1.6.4, CO 2:55). Calvin (Inst. 1.7.1, CO 2:56) emphatically stresses that the authority of Scripture is not derived from human beings, but only from the Spirit. Its authority cannot be proved through rational arguments, nor does it depend on the decisions of councils. Only faith can attest to the authority of Scripture:

The testimony of the Spirit is superior to reason. For as God alone can properly bear witness to his own words, so these words will not obtain full credit in the hearts of men, until they are sealed by the inward testimony of the Spirit. (Calvin 2008, Inst. 1.7.4, CO 2:63)

Knowledge of ourselves consists of two parts, namely knowledge of the gifts with which the human being was originally endowed, and knowledge of the 'miserable ruin into which the revolt of the first man has plunged us' (Calvin 2008, Inst. 1.1.1, CO 2:32).

Whereas the universe forms the macrocosm of God's works, the human person constitutes a 'microcosm' of God's works in the sense that he or she is the brightest mirror of God's glory (Calvin 2008, Inst. 1.5.3, CO 2:43, 1845:93, CO 31:88). Calvin describes the human being as 'a rare specimen of divine power, wisdom and goodness' (Calvin 2008, Inst. 1.5.3, CO 2:43). The difference between the human and other creatures is that the human is created after the image of God and possesses the 'light of understanding'. Having 'been endued with reason' humans rank higher than all other creatures in the creaturely realm, because they are able to acknowledge God and stand in a relationship with him (Calvin 1847b:32, CO 47:4). The role that Calvin ascribes to reason should thus not be underestimated. Calvin is no fideist or irrationalist, but he regards reason and understanding as a special and defining endowment of God that separates the human being from the rest of creation and connects him or her to God. This emphasis on the importance of reason and will is closely connected to 
the relational nature of his theology. Unlike the Schoolmen who portrayed the relationship between God and human beings as existing in a gradation of being, Calvin emphasises the personal relationship between God and the human being in which reason and will plays an important role. His theology is fundamentally dynamic, and as such, represents a fundamental shift away from Scholasticism's static ontology.

Calvin's understanding of the imago Dei is characterised by a dualism between soul and body. The soul is in Calvin's thought the primary seat of the imago Dei, the noblest part of the human being, whilst the body is image of God in a secondary sense. ${ }^{3}$ Calvin regards the human soul as 'immortal essence', which not only has the ability to transcend the body, but also has the innate capacity to conceive of God. He ascribes this ability of the soul to God engraving a sense of the divine in the human mind:

That there exists in the human minds and indeed by natural instinct, some sense of deity, we hold to be beyond dispute, since God Himself, to prevent any man from pretending ignorance, has endued all men with some idea of his Godhead. (Calvin 2008, Inst. 1.3.1, CO 2:36)

The human being is thus more than a living body, he is a living soul that has a mind in order to meditate on the heavenly life in which he finds the true destiny of his being in the image of God' (Torrance 1957:31). By depositing the seed of religion on our minds God shows his felicity towards all people and provides us with the capacity to discern his creative 'wisdom' (Calvin 2008, Inst. 1.5.1, 1.5.2, CO 2:41, 42).

Calvin consistently describes reason and will as the two main faculties of the soul (cf. Calvin 2008, Inst. 1.15.7, CO 2:142). Reason makes moral judgments, whilst the will makes choices in accordance with the judgments of the intellect (see Calvin 2008, Inst. 1.15.7, 1.15.8, CO 2.142, 2.148; 2009:94, SC 11/1:59). At times Calvin describes reason as the 'primary seat' of the imago Dei, ${ }^{4}$ because reason is the faculty unique to the human being and through which he or she surpasses all other creatures (cf. Calvin 2008, Inst. 1.15.3, CO 2:119). The uniqueness of reason is manifested in it being the 'guide and ruler' of the soul that also governs the will (Calvin 2008, Inst. 1.15.7, CO 2:141). By endowing the human being with reason, God enabled him or her to 'discern good from evil', justice from injustice and most importantly, to restrain his or her sensual passions (Calvin 2008, Inst. 1.15.8, CO 2:142; 1996:76, $\mathrm{CO} 6: 285)$. Reason is therefore 'one of the essential properties of our nature' that distinguishes us from 'lower animals' and 'inanimate objects' (Calvin 2008, Inst. 2.2.17, CO 2:199).

Though unique, reason is not an end in itself, but its purpose is to direct us to God. The defining feature of reason in its

3.In his early work, Psychopannychia, Calvin held that the body does not exhibit the image of God, because God cannot be represented by a physical substance. Later on, however, he revised this position by describing the body as radiating God's glory in a secondary sense (see Calvin 1958:423, CO 5:180; 2009:89-106, SC 11/154-67; 2008, Inst. 1.15.3, CO 2:138).

4.Anselm and Peter Lombard, tended to define the imago Dei exclusively in cognitive terms (see Van Vliet 2009:37). This, however, cannot be said of Calvin. In general he locates the imago Dei in all those qualities that elevates human beings above the locates the imago Dei in all those qualities that elevates human beings above the
creaturely realm, though he regards the human's ability to reason and his will as the creaturely realm, though he regards the human's abilt
most outstanding characteristics of the imago Dei. original form was that it allowed the human person not only to govern earthly life, but also 'to rise up to God and eternal happiness'. The human being was in fact capable of 'comprehending his eternal destiny', which signifies an ability to stand in an immediate relation to God who is the source of life (Calvin 2008, Inst. 2.1.1, 1.15.8, CO 2:175, 148). For Calvin this capacity of reason to 'ascend' to God is the most important feature of reason in its original state. ${ }^{5}$

\section{Human reason and sin}

Whereas Augustine located the first sin in pride, Calvin (1847a:153, CO 23:60) ascribes it to the human's longing for illicit knowledge. By underscoring the noetic effects of sin, Calvin shifts the focus away from Augustine's preoccupation with the will to the role of the mind in conjunction with the will (cf. Pitkin 1999:353). Sin is essentially a failure to know God and the self. True knowledge is not possible, because sin defects the very origin of true knowledge: our relation with God. Since the human being is no longer capable of knowing God, he or she is not able to know him- or herself either. The metaphor Calvin repeatedly uses is that of blindness. The mind's corruption exists in a fundamental religious blindness - the human being is plunged into darkness:

Men are now widely distant from that perfectly holy nature with which they were originally endued; because their understanding, which ought to have shed light in every direction, has been plunged in darkness, and is wretchedly blinded. (Calvin 1847b:33, CO 47:6)

The effects of this blindness are radically incisive and wideranging. No person is able to penetrate into the 'kingdom of God' through his own sagacity (cf. Calvin 1847b:38, CO 47:9). In his commentary on 1 Corinthians 2:10, Calvin (1849:110, CO 49:341) states that God has 'shut up all mankind in blindness' by taking 'away from the human intellect the power of attaining a knowledge of God by its own resources'.

Knowledge of God is out of reach of all human beings, because the human mind 'has become a kind of labyrinth' (Calvin 2008, Inst. 1.5.12, CO 2:49). No longer able to 'ascend' to God, the human being is engulfed in darkness. Though the manifestation of God's works are as bright as ever, the human 'has no eyes to perceive it' (Calvin 2008, Inst. 1.5.14, CO 2:51, 52). The range of this blindness becomes clear when we 'test our reason by the divine Law, which is a perfect standard of righteousness' (Calvin 2008, Inst. 2.2.24, CO 2:205).

Calvin (2008, Inst. 2.1.5, CO 2:190) ascribes the spread of this blindness from the first human beings to the rest of humanity to a 'hereditary corruption'. Adam was not merely a 'progenitor', but 'a root' whose corruption penetrated the whole human race in the same way that corrupt branches proceed from a corrupt root (Calvin 2008, Inst. 2.1.6, 2.1.7,

5.The theme of descent and ascent permeates Calvin's theology. We already observe this in his discussions on the original state of reason. The ascent-descent theme is not exclusive not exclusive to Calvin's theology, but he picks up on a Scholastic motif. Augustine, for instance, focused on the soul's ascent to God and Aquinas on ascent through grace in an ontological sense. Calvin, indeed, starts with the Augustinian notion that the soul was originally capable of ascending to God through the mind, but he eventually constructed the theme in pneumatological terms. We 'ascend' to God through the work of the Spirit that unites us to Christ. 
CO 2:180). Sin is therefore systemic in nature - when Adam sinned he 'transmitted the contagion to all his posterity'. Adam's posterity is punishable, not because Adam's sin pertains to them, but because they are infected by the same corruption (Calvin 2008, Inst. 2.1.6, CO 2:180). ${ }^{6}$

The 'blindness' under which human beings labour, is, according to Calvin (2008, Inst. 1.4.1, CO 2:38), 'almost invariably accompanied by vain, pride and stubbornness. Since the human being is no longer able to 'ascend' to God and observe his holiness and perfection, he or she is not able to understand his or her own deformity either, and therefore becomes self-inflated. Cut off from its source of knowledge and deprived of the light of God, the human being becomes 'carnally' minded (Calvin 2008, Inst. 2.3.1, CO 2:209). Calvin (2008) states thus:
the mind is so entirely alienated from the righteousness of God that he cannot conceive, desire, or design anything but what is wicket, distorted, foul, impure and iniquitous; that his heart is so thoroughly envenomed by sin that it can breathe out nothing but corruption and rottenness; that if some men occasionally make a show of goodness, their mind is ever interwoven with hypocrisy and deceit, their souls inwardly bound with the fetters of wickedness. (Inst. 2.5.19, CO 2:247)

Not only does the 'blindness' that sin cause, pervert the human mind, but it also leads to the creation and veneration of idols to replace God (Calvin 2008, Inst. 1.5.12, CO 2:50). One can hardly find a person who does not 'fashion for himself an idol or specter in place of God' (Calvin 2008, Inst. 1.5.12, CO 2:49). In fact, reason itself becomes an idol. No longer is the human being willing to consult God's will and to confine his or her reason to the boundaries of God's will, but reason itself is placed higher than God (cf. Calvin 2008, Inst. 1.14.1, CO 2:117). This sinful inclination to devise shapes of deity 'is diametrically opposed to the divine nature' and corrupts and adulterates true religion (Calvin 2008, Inst. 2.8.17, CO 2:279). For Calvin, the human's pride and self-adoration is the exact opposite of the image of God that is directed at reflecting God's virtues and heightening God's glory. Instead the human person steals 'divine glory for himself' (Waugh 2010:14).

Calvin initially held that the image is totally destroyed by the Fall and that the human mind is totally perverted. The following remark in Bondage and Liberation of the Will (1543) serves as an example:

For all human faculties are corrupt, so that of themselves they can bear only evil fruit. In addition this grace is not given to all without distinction or generally but only to those whom God wills; the rest to whom it is not given, remain evil and have absolutely no ability to attain to the good because they belong to the mass that is lost and condemned. (Calvin 1996:136, CO 6:326)

6.Calvin's explanations on the transmission of sin vary throughout his works. In his reply to Pighius he made use of the Scholastic notion of 'habit'. Habit denotes a quality accidental to substance. Sin changes human nature's quality (habit) of will so that the human being becomes inclined to sin. However, Calvin did not employ this argument in his later works. At times Calvin also states that God denuded all of humankind from their supernatural gifts after the Fall because of the sin of Adam (Calvin 2008, Inst. 2.2.12, 2.2.13, CO 2:196, 2:197). Th transmission of sin is thus the cause of God's punishment. Yet, in his Commentary on Psalms 51:7 Calvin states that the question on the transmission of sin is no important and that it is not sensible to enter into the labyrinth of such discussions (Calvin 1845:291, CO 31:514).
Though, it was clearly not Calvin's intention to dehumanise the human being. ${ }^{7}$ Pighius accused Calvin of demeaning the human being to a 'brute beast' by viewing the image as lost after the Fall (Calvin 1996:38-39, CO 6:257). If the human being no longer bears the image of God, no social ethics is possible. Possibly as a result of his debate with Pighius, Calvin modified his position on the imago Dei in his later works.

The challenge Calvin faced, was not to diminish God's radical grace by ascribing too much to human capacity, but conversely also to avoid dehumanising the human being to such a degree that virtue and a shared social ethics becomes impossible. Calvin responded to the impasse by modifying his initial position that the imago Dei is totally destroyed to one that posits the total depravity of the image. Total depravity denotes that there is no part in the human being that is not vitiated by sin and who is blameless. Even the best works of the human person are corrupted by sin. Yet, this does not mean that the human person bears no capacity for the good (Bouwsma 1988:139).

Calvin's solution was to distinguish between the supernatural and natural gifts of the human being. The supernatural gifts such as faith, charity, holiness and uprightness that enable the human being to attain the heavenly life are totally destroyed, so that no-one can ascend to God; yet some vestiges of the natural gifts remain that enable the human person to have a sense of right and wrong (Calvin 2008, Inst. 2.2.12, CO 2:195). These natural remnants of the imago Dei are not sufficient to attain salvation and amount to nothing with regard to our relationship with God, but it does make it possible for human beings to act morally:

In this corrupted and degenerate nature light has been turned into darkness. And yet he (John) affirms that the light of understanding is not wholly extinguished; for amidst the darkness of the human mind, some remaining sparks of the brightness still shines ... natural reason will never direct men to Christ; and as their being endued with prudence for regulating their lives, or born to cultivate the liberal arts and sciences, all this passes away without yielding any advantage. (Calvin 1847b:33, 34, CO 47:5, 6)

The survival of the remnants are not attributable to any indestructible characteristic of the human being, but is solely the result of God's common grace ${ }^{8}$ that preserves humanity from descending into chaos (cf. Calvin 2008, Inst. 2.2.14, CO 2:198). In Bondage and Liberation of the Will, Calvin (1996) states the difference between God's common grace and special grace as follows:

We exist and move in one sense as human beings and in another as the sons of God. The former grace is the possession of everyone, but the latter is granted specially to the elect. The former is in a certain way implanted in our nature, but the latter is given to man as a supernatural gift. (p. 167, CO 6:347)

7.Calvin initially did not view the loss of the imago Dei as something that dehumanises the human being, because God maintains the humanity of a person through his common grace. Later on, he seemingly realised that this position is untenable. If the sinful human being is still a recipient of God's common grace, $h$ God in some sense. Some vestiges of the image must therefore have survived.

8.Calvin never uses the phrase common grace, but the idea is prevalent in his works. 
Common grace entails that, though the Spirit does not work faith in the reprobate, it is still present in his or her life since all things are filled and moved by the Spirit. Behind every distinguished act there is the inspiration of the Spirit (Calvin 2008, Inst. 2.2.16, 17, CO 2:199, 200).

Calvin regards God's preservation of the faculties of reason and will as the two most important remnants of the imago Dei. These faculties are, after all, related to the total nature of the human person, who is in essence a rational being. If God had not preserved reason and will, human nature itself would have been destroyed:

Had God not spared us, our revolt would have carried along with it the entire destruction of nature (Calvin 2008, Inst. 2.2.17, CO 2:199)

The question is: In what sense were reason and will corrupted by $\sin$ ? Calvin addresses the issue by distinguishing between heavenly and earthly knowledge. Heavenly knowledge pertains to 'true knowledge of God, the method of righteousness and the mysteries of the kingdom' (Calvin 2008, Inst. 2.2.13, CO 2:197). Natural knowledge consists in the human person possessing some 'seed of religion' and being able to distinguish between good and evil (Calvin 1847b:34, CO 47:7). It entails a kind of 'universal reason naturally implanted' in human beings that relate to matters of policy, economy, mechanical arts and liberal studies (Calvin 2008, Inst. 2.2.13, 14, CO 2:197, 198). As far as heavenly things are concerned, the human being is totally blind; ${ }^{9}$ he or she cannot ascend to God without the guidance of the Spirit. ${ }^{10}$ Yet, in earthly matters the minds of all people 'have impressions of civil order and honesty'. All societies need to be governed by rules and all human beings are able to comprehend these rules (Calvin 2008, Inst. 2.2.13, CO 2:197). Calvin (2008, Inst. 2.2.13, CO 2:197) states that in regard to the constitution of the present life no man is devoid of reason'. In fact, he (Calvin 2008) displays a positive attitude towards the achievements of human culture and regards it as emanating from the Holy Spirit that bestows his gifts on humanity despite sin:

The human mind, however much fallen and perverted from its original integrity, is still adorned and invested with admirable gifts from its Creator. If we reflect that the Spirit of God is the only fountain of truth, we will be careful, as we would avoid offering insult to him, not to reject or condemn truth wherever it appears. (Inst. 2.2.15, CO 1:273-274)

Calvin proceeds to deduce from our possession of natural knowledge the existence of a natural law that functions within the ambit of God's common grace. Even gentiles have a sense of righteousness, because God has engraved

9 .Human beings have the seed of religion implanted in them, but this is not sufficient to enter in communion with the true God (Calvin 1845:102, CO 31:91).

10.Calvin (2008, Inst. 2.3.1, CO 2:209, 210) disassociates himself from the teachings of Rome that held that the human being was only corrupted with regard to his sensual desires, whilst the faculties of reason remained undamaged. Instead he maintains that the mind itself must be renewed, because there is no part of the human being that is not perverted or corrupted (cf. Torrance 1957:90). his natural law on our minds. Natural law is naturally engraved in all people, works through the human conscience, is discernible by all people and provides a right course for conduct (Calvin 2008, Inst. 2.2.22, CO 2:203). In contrast to some natural philosophers of his time, Calvin (2008, Inst. 1.16.3, CO 2:146) does not regard the natural law as a perpetual law that functions on its own; rather it is sustained by God himself who reigns providentially over all things. Natural knowledge is thus not a feature of nature, but a special gift of God (Calvin 2008, Inst. 2.3.4, CO 2:212). In fact, God governs the wills of men and the course of history exactly according to the course he has destined (Calvin 2008, Inst. 1.16.8, CO 2:151).

In light of the above discussion we might state at this stage that Calvin (2008, Inst. 2.2.13, CO 2:197) regards a shared social ethos as possible, not because rules are imposed unilaterally by divinely appointed governments on people as Gregory suggests, but because human beings are innately 'social animals' with a sense of justice. This natural sense of justice is not isolated to an ability to adhere to rules, but all human beings are capable of virtuous behaviour by following the course of natural law:

If the gentiles have the righteousness of the law naturally engraved on their minds, we certainly cannot say that they are altogether blind as to the rule of life. Nothing, indeed, is more common, than for man to be sufficiently instructed in a right course of conduct by natural law (Calvin 2008, Inst. 2.2.22, CO 2:203).

Calvin points to the fact that there have been through the ages many people who, guided by nature, strived towards virtue. Through their zeal and honesty they have given proof that there was some purity in their lives (Calvin 2008, Inst. 2.3.3-4, CO 1:292-294). This is due to the work of the Holy Spirit who is present in the lives of all people, even the reprobate. His presence in the lives of unbelievers consists of him bestowing virtues as gifts (Inst. 3.14.2, CO 2:565). To say that a person is depraved does not mean, for Calvin, that such a person is morally considered bad ${ }^{11}$ or incapable of virtue (Gerrish 1981:220). In fact, Calvin (2008, Inst. 2.2.15, 16$, CO $2: 198,199)$ expresses appreciation for profane authors that produce works of 'admirable light of truth', and men with 'excellent' gifts who use it to the 'common benefit of all mankind'. Calvin also regards the arts and sciences not only as legitimate, but as essential aids for the common life (cf Engel 1988:201; Calvin 1847a:86, CO 23:45).

But if the Lord has been pleased to assist us by the work and ministry of the ungodly in physics, dialectics, mathematics and other similar sciences, let us avail ourselves of it, lest by neglecting the gifts of God spontaneously offered to us, we be justly punished for our sloth. (Calvin 2008, Inst. 2.2.16, CO 2:199)

11.It is important to note that Calvin does not equate virtuous moral acts and good works with each other. Calvin defines good works in a very narrow sense. Good
works aim at glorifying God. Beneficial acts for humanitarian ends might be works aim at glorifying God. Beneficial acts for humanitarian ends might be commendable and regarded as virtuous, but if they are driven by wrong inner intentions they are not blameless (Calvin 2008, Inst. 3.14.3, CO 2.565). Only deed that emanate from a gratitude for God's grace can be regarded as 'good' in the soteriological sense of the word. Human virtue thus, though possible to exercise through the light of natural reason, amounts too little if not inspired by the Holy Spirit (cf. Calvin 2008, Inst. 2.2.9, CO 2:193). 
Yet, whilst Calvin shows admiration for the natural gifts of humans, maintains that the human person's natural knowledge was not destroyed by sin, and believes that God's common grace makes a social ethics possible, he nevertheless consistently reminds his readers of the corruption of our natural knowledge and the boundaries of natural reason. Human beings are, according to Calvin (2009:490), inclined to apply their natural knowledge to wrong ends, because their minds are alienated from God. The 'common light of reason' God implanted in human persons is far inferior to faith, and cannot penetrate into the kingdom of God (Calvin 1847b:38, CO 47:9). The human person is thus not able to worship God truthfully through the means of natural law (Calvin 2008, Inst. 2.8.1, CO 2:267). Actually, natural reason is so corrupted that Calvin (2008, Inst. 2.2.12, CO 2:196) calls it a 'shapeless ruin'. Every attempt to understand God through natural reason leads to perversion and alienates the human person only more from God (cf. Torrance 1957:150). For Calvin, the right exercise of reason can only exist within the boundaries of grace (Torrance 1957:116). ${ }^{12}$ From the perspective of God all earthly knowledge, detached from heavenly knowledge, is vain and fleeting. Engel (1988:91) rightly notes that, for Calvin, earthly knowledge has a 'relative though positive value'. It contributes to our understanding of earthly reality, but it is of no use for understanding eternal reality. To understand the eternal things we need grace.

\section{Grace and reason}

In Calvin's thought knowledge of God can only be acquired through an act of God's grace that goes 'beyond the natural capacity of the human mind' (Torrance 1957:129). Humans cannot ascend to God through natural reason, because natural knowledge tends to descend into superstition. In order for us to ascend to God, God first needs to descend to us. Only the affective pull of God can draw us into communion with God. This descent takes place through Christ, who becomes flesh and dies for our sins on the cross, God, who accommodating himself to our capacity in his Word, and the Spirit that dwells in us.

To acquire heavenly knowledge we first of all need to be illuminated by the Spirit of God (Calvin 1847b:38, CO 47:7). The Spirit opens our eyes for our sins, state of disgrace and spiritual nakedness before God through the mirror of the Word. True to the noetic orientation of his theology, Calvin always relates the work of the Spirit to the Word. The Word is the instrument whereby the Spirit calls us, works faith in us and sanctifies us. Calvin (2009:4, SC 11/1:2; 2008, Inst. 1.6.1, CO 2:53) therefore calls the Word our 'eyeglasses' that 'dissipates the darkness and shows us the true God clearly'. Through these metaphors he indicates that we can only know God through acknowledgement of his revelation. No knowledge of God is possible 'apart from the gracious will of God to reveal himself to us' (Torrance 1957:178). God reveals himself to us through comparisons we know, in order to accommodate our limited capacity (Calvin 1849:188, CO 50:47). This means that our knowledge of God is essentially analogical, not in the sense of analogia entis, but in the form of an 'analogia fidei which is subject to God's word' (Torrance 1957:128, 149). Nothing in human nature itself, such as an analogy of being or a remnant of the image, can prepare us for grace (Torrance 1957:134). Only through the Spirit and Word our minds are raised up to know God:

It is only when the human intellect is irradiated by the light of the Holy Spirit that it begins to have a taste of those things which pertain to the kingdom of God. (Calvin 2008, Inst. 3.2.34, $\mathrm{CO} 2: 427)$

The illumination of the Spirit is not merely a rekindling of the mind, but especially of the heart, which is the seat of our affections (Calvin 2008, Inst. 3.2.8, CO 2:404). For Calvin, knowledge is, after all, about attaining a wisdom that is practical and relational in nature, not theoretical and speculative. Knowledge is not merely experimental in character, but relates to the whole personality of the human person. The result of the Spirit's illumination is that we progress in the knowledge of ourselves and that we long for God's mercy (Calvin 2008, Inst. 2.2.10, 11, CO 2:194, 195). In doing so, the Spirit directs us to Christ, because God can only be known in Christ who is the brightest image of God. No knowledge of God is effectual without knowledge of the atoning work of Jesus Christ who restored through his death and resurrection the perverted created order (Calvin 2008, Inst. 2.6.1, CO 2:247, 248; Torrance 1957:169). To understand the heavenly things we need to know Christ who descended to earth so that we can ascend to heaven; who appropriated mortality so that we can acquire immortality; and who submitted himself to weakness so that we can receive strength (Calvin 2008, Inst. 4.17.2, CO 2:1003).

The Spirit enables us to 'ascent' to our Saviour by working in us a faith in Christ that is a 'firm and sure knowledge' of God's favour towards us (Calvin 2008, Inst. 3.2.7, CO 2:403). Faith is a gift of God since God invites and rouses the elect by 'forming, bending and directing our hearts to believe' (Calvin 1996:204, CO 6:374). It is not a 'bare or cold knowledge' that asks for 'proofs or probabilities on which to rest our judgment', but it subjects the intellect to God's transcendent revelation (Calvin 2008, Inst. 1.7.5, CO 2:60; 1847b:44, CO 47:13). Faith is about 'certainty' rather than 'discernment' (Calvin 2008, Inst. 3.2.14, CO 2:410). Calvin (2008) therefore states:

The first step in true knowledge is taken, when we reverently embrace the testimony which God has been pleased therein to give of himself. (Inst. 1.6.2, CO 2:54)

Since faith is part of our regeneration, it gives us entrance into the kingdom of God and puts us into possession of God's blessings as adopted children of God (Calvin 1847b:44, CO 47:13).

Flowing from our justification, Christ sanctifies us through his Spirit (Calvin 2008, Inst. 3.2.9, CO 2:403, 404; 1847b:44, 
CO 47:13). No person will ever know Christ 'aright without at the same time receiving the sanctification of the Spirit' (Calvin 2008, Inst. 3.2.8, CO 2:404). Sanctification entails that our knowledge is renewed by the Holy Spirit, not merely in the sense that the mind is enlightened, but the whole of the human person is transformed so that the believer is able to shine forth the glory of God (Calvin 1851:211, 212, CO 52:121, 122). Sanctified reason is characterised by a denial of the self and submission to the Spirit that illuminates us through his Word (Waugh 2010:13). The contradictions between depraved reason and sanctified reason in Calvin's thought is clear: whereas depraved reason posits its own autonomy, sanctified reason decentres the human being and submits the human person to the Word of God. Whereas depraved reason is characterised by self-affirmation; sanctified reason is characterised by self-emptying. Whilst depraved reason is prone to superstition, sanctified reason is able to acquire true knowledge of the heavenly things. Where depraved reason seeks after self-glory, sanctified reason seeks the glory of God.

Canlis (2010:247) rightly notes that Calvin regards sanctification as an 'entire reorientation from the autonomous self to the self-in relationship'. The fundamental premise of Calvin's soteriology is that human beings cannot exist on their own, but finds their destiny by being engrafted in Christ. When we live in Christ his 'wisdom' and 'will' rule all our actions (Calvin 2008, Inst. 3.7.1, CO 2:505). True knowledge is only possible through Christ who is the light of all truth. Calvin therefore admonishes natural philosophers that reason needs to give way and submit to the Holy Spirit so that 'the man himself no longer lives, but Christ lives and reigns in him' (Calvin 2008, Inst. 3.7.1, CO 2:506). As long as humanity maintains the autonomy of reason it is on a selfdestructive course of alienation from God, because the true identity of human beings does not lie within themselves, but in their bond with Christ through the Spirit.

Though the sanctification of reason is an on-going process, because, as long as we are in the 'prison of our body', we constantly struggle against our fleshly desires and natural inclinations that also affect reason (Calvin 2008, Inst. 3.3.20, CO 2:450). The Spirit's work in us is neither coercive, ${ }^{13}$ nor instantaneous in nature, but he gradually transforms us by increasing our faith and knowledge of God (cf. Calvin 2008, Inst. 3.2.33, CO 2:426; 1849:187, CO 50:47). Once reason finds its orientation in faith it 'knows that the knowledge of God exceeds the natural capacity of man'. It then strives to grow in the knowledge of God, the knowledge of his favour towards us and how to regulate our conduct in accordance with his will (cf. Torrance 1957:146; Calvin 2008, Inst. 2.2.18, CO 2:200). Yet, our knowledge of God will always be 'obscure and slender' in the present. Sanctification does not mean that the human can attain perfect heavenly knowledge. However, God will allow us with the knowledge we need in this life as far as our limited capacity permits (Calvin 1849:188).

13.Calvin held that the human faculties act when acted upon by the Spirit. Thus, though the Spirit works faith in us, he does not bring it about through coercion. though the Spirit works faith in us, he does not bring it about through coercion.
Faith is properly an act of ours, because the Spirit does not circumvent the human faculties whilst working faith in us.

\section{Conclusion}

We now return to Gregory's accusation against the Reformers and ask whether it is true with regard to Calvin: Does Calvin's view of the perversion of human reason allow space for a social ethics that integrates virtue with rules, or did Calvin revert to a formal kind of social ethics that enforce rules on society through divinely appointed rulers?

Our investigation has shown that Calvin did not reject natural reason out of hand. He was critical of Scholasticism's idea of teleological reason, not of reason altogether (cf. Van Drunen 2004:512). In general he regarded natural reason as an instrument God uses in his providential plan to preserve creation from descending into chaos. Natural reason does supply humans with a sense of justice that is required for a social ethics. Calvin also regarded virtue as attainable through natural reason. Being depraved does not mean that all people are necessarily morally considered bad or incapable of displaying virtues.

Yet, Calvin did share nominalism's scepticism of the potential of human reason. He did not accept the Aristotelian or Scholastic notion that reason is scarcely impaired by sin and is by nature capable of being virtuous. Calvin regarded this position as emanating from a pagan influence on Christian theology brought about by Origen and sustained by the papacy (cf. Bouwsma 1988:138). In Calvin's opinion, non-believers are capable of virtue, not because of the natural capabilities of reason, but because of God's common grace that infuses natural reason. However, the moral and civil virtues that non-believers display, amounts to nothing in a soteriological sense and cannot secure the human being's salvation. To find true healing and attain heavenly knowledge, the mind needs to be renewed from without.

The weakness of Gregory's argument with regard to Calvin is twofold. He first of all does not take into account that Calvin changed his initial position of the total destruction of the imago Dei to one of the total perversion of the image, but wrongly asserts that the Reformers regarded the image as destroyed (cf. Gregory 2012:207). Natural reason is one of the remnants that Calvin believed survived in the human being despite sin. Secondly, he gives no consideration to Calvin's teaching of common grace, which is really the tool Calvin uses to make a cohesive social ethics possible. According to this doctrine all human beings are capable of virtue, because God bestows his common grace on all people. Calvin, thus, did leave room for the possibility that a social ethics may be constructed on the basis of both virtue and rules. His difference with Scholasticism centred, not as Gregory seems to think on the question whether human virtue is possible, but on the origin and the soteriological value of human virtue. Against Scholasticism Calvin firstly stated that human virtue does not emanate from the innate capabilities of the human person, but from God's grace, and secondly that human virtues have no soteriological significance, because it is, in the end, not of our own making, but gifts from God himself. 


\section{Acknowledgements}

The author received financial assistance for this project from the National Research Foundation of South Africa. All views expressed in the article are opinions of the author not the NRF.

\section{Competing interests}

The author declares that he has no financial or personal relationship(s) that may have inappropriately influenced him in writing this article.

\section{References}

Aquinas, T., 1989, Summa Theologiae, transl. \& ed. T. McDermott, Christian Classics, Westminster, Maryland.

Aquinas, T., 2005, Disputed Questions on the Virtues, transl. E.M. Atkins, ed. E.M. Atkins \& T. Williams, Cambridge University Press, Cambridge.

Billings, J.T., 2005, 'United to God through Christ: Assessing Calvin on the question of deification', Harvard Theological Review 98(3), 315-334. http://dx.doi. org/10.1017/S0017816005000994

Bouwsma, W.J., 1988, John Calvin. A Sixteenth Century Portrait, Oxford University Press, Oxford.

Calvin, J., 1845, The Book of Psalms, transl. J. King, Calvin Translation Society, Edinburgh.

Calvin, J., 1847a, Commentaries on the first book of Moses called Genesis, transl. J. King, Calvin Translation Society, Edinburgh.

Calvin, J., 1847b, Commentary on John, vol. 1, transl. W. Pringle, Calvin Translation Society, Edinburgh.

Calvin, J., 1849, Commentary on the Epistles of Paul to the Corinthians, vol. 1 \& 2 , transl. J. Pringle, Calvin Translation Society, Edinburgh.
Calvin, J., 1851, Commentary on the Epistles of Paul to the Philippians, Colossians and Thessalonians, transl. J. Pringle, Calvin Translation Society, Edinburgh.

Calvin, J., 1859, Commentary on the epistle of Paul the Apostle to the Romans, transl. J. Owen, Calvin Translation Society, Edinburgh.

Calvin, J., 1958, 'Psychopannychia', in H. Beveridge (ed.), Tracts and Treatises in defense of the Reformed faith, vol. 3, Eerdmans, Grand Rapids.

Calvin, J., 1996, The bondage and liberation of the will, transl. A.N.S. Lane \& G.I. Davies, Baker Books, Grand Rapids.

Calvin, J., 2008, Institutes of the Christian Religion, transl. H. Beveridge, Hendrickson Publishers, Peabody.

Calvin, J., 2009, Sermons on Gen 1-11, transl. R.R. McGregor, Banner of Truth Trust, Edinburgh.

Canlis, J., 2010, Calvin's Ladder: A spiritual theology of ascent and ascension, Eerdmans, Grand Rapids.

Edgar, B., 2010, 'Calvin and the natural order: Positives and problems for science-faith dialogue', Christian Perspectives on Science and Dialogue, pp. 1-15.

Engel, M.P., 1988, John Calvin's perspectival anthropology, Scholars Press, Atlanta.

Gerrish, B.A., 1981, 'Mirror of God's goodness: Man in the theology of Calvin', Concordia Theological Quarterly 45(3), 211-222.

Gregory, B., 2012, The Unintended Reformation: How a religious revolution secularised society, Belknap Press, London. http://dx.doi.org/10.4159/ harvard.9780674062580

Pitkin, B., 1999, 'Nothing but concupiscence: Calvin's understanding of sin and the Via Augustini', Calvin Theological Review 34, 347-369.

Torrance, T., 1957, Calvin's doctrine of man, Eerdmans, Grand Rapids.

Van Drunen, D., 2004, 'The context of natural law: John Calvin's Doctrine of Two Kingdoms', Journal of Church and State 46(3), 503-525. http://dx.doi. org $/ 10.1093 / \mathrm{jcs} / 46.3 .503$

Van Vliet, J., 2009, Children of God. The Imago Dei in John Calvin and His Context, Vandenhoeck \& Ruprecht, Göttingen.

Vorster, N., 2013, 'Die Westerse mens en betekenisverlies', Tydskrif vir Geesteswetenskappe 53(1), 30-44.

Waugh, B.G., 2010, 'Historical Studies: Reason within the limits of revelation alone: John Calvin's understanding of human reason', Westminster Theological Journal 72, 1-21. 